\title{
GEJALA PTSD (POST TRAUMATIC STRESS DISORDER) AKIBAT BENCANA BANJIR PADA MASYARAKAT KELURAHAN MERANTI RUMBAI PESISIR PEKANBARU
}

\author{
Fitry Erlin*, Icu Yuanda Sari \\ STIKes Payung Negeri Pekanbaru \\ Koresponden E-mail: fitryerlin@gmail.com
}

\begin{abstract}
Post-traumatic stress disorder or PTSD is an anxiety disorder that develops through exposure to a traumatic event, stressful situations, severe torture, and natural or catastrophic disasters due to human negligence. These disorders could be include 3 main symptoms, namely the feeling of re-experiencing, the desire to avoid all stimuli associated with traumatic events (avoidance), and increased awareness of the arousal, which is experienced over a period of a month or more. This study aims to find a description of the symptoms of PTSD (Post Traumatic Stress Disorder) due to flooding on Meranti Pandak Village RT 02 RW 012 Rumbai Pesisir District of Pekanbaru. Types of quantitative research and descriptive design. The study was conducted on 16 June - 01 July 2019 in Meranti Pandak Village, Rumbai Pesisir District with 45 respondents. Data collection techniques using a questionnaire. This study shows that from 45 respondents studied there were symptoms of repeated experiences 27 people (60.0\%) experienced, avoidance symptoms 37 people (82.2\%) experienced, negative symptoms of change 10 people (22.2\%) experienced, symptoms of stimulation changes 34 people (75.6\%) experienced, who experienced all the symptoms of PTSD 3 people (6.7\%), so it can be concluded that found the symptoms of PTSD (Post Traumatic Stress Disorder) due to flooding It is expected that health workers provide health education and conduct ongoing evaluations to people affected by symptoms.
\end{abstract}

\section{Keywords: PTSD (Post Traumatic Stress Disorder), Flood Disaster}

Bencana merupakan gangguan atau kekacauan pada pola normal kehidupan. Gangguan atau kekacauan ini biasanya terjadi secara tiba-tiba, tidak disangka dari wilayah cakupan cukup luas atau menimbulkan banyak korban. Bencana merupakan fenomena yang terjadi karena komponen-komponen ancaman dan kerentanan bekerja sama secara sistematis yang didorong oleh pemicu sehingga menyebabkan terjadinya resiko bencana pada komunitas (United Nation Development Programme And Government Of Indonesia, 2012).

Bencana alam yang terjadi di Indonesia terbagi menjadi dua yaitu bencana yang berasal dari alam dan bencana dengan adanya campur tangan manusia. Contoh bencana alam yang berasal dari alam adalah gunung meletus, badai dan tsunami dan contoh bencana alam dengan adanya campur tangan manusia adalah kebakaran dan banjir. Bencana alam tersebut disebabkan manusia mengubah sistem ekologi yang sudah ada (Daryono,2010).

Banjir merupakan bencana besar di dunia. Kejadian dan korban bencana banjir menempati urutan pertama di dunia yaitu mencapai $55 \%$. Persentase kejadian banjir di Indonesia mencapai 38\% dari seluruh kejadian bencana. Berdasarkan data Badan Nasional Penanggulangan Bencana (BNPB) mencatat sebanyak 787 banjir melanda Indonesia sepanjang tahun 2017, sehingga bencana banjir menempati urutan pertama.

Berdasarkan data Badan Penanggulangan Bencana Daerah (BPBD) Riau, tercatat tujuh kabupaten dan kota di Riau yang masih di terjang banjir, yakni Kabupaten Kampar, Rokan Hulu, Rokan Hilir, Kota Pekanbaru, Bengkalis, Kuantan Singingi dan Pelalawan. Berdasarkan data BNPB Tahun 2018 jumlah kejadian banjir di Riau 15 kali dari total 54 seluruh kejadian. Kejadian yang paling banyak terjadi di kabupaten rokan hulu yaitu dengan jumlah kejadian 6 kali (BNPB, 2018).

Banjir yang terjadi di beberapa daerah di Indonesia pada umumnya selalu dikaitkan dengan adanya aktifitas alih fungsi lahan yang marak terjadi di daerah hulu sungai. Namun, aktifitas manusia di daerah hulu sungai tidak saja dapat mengganggu sistem aliran air. Banyak faktor lain yang bisa menyebabkan banjir di dataran rendah. Kecuali bila dilakukan penebangan dan alih fungsi lahan besarbesaran yang akan mengakibatkan tingginya tingkat erosi. Selain itu banjir disebabkan oleh curah hujan yang tinggi di atas normal, sehingga sistem pengaliran air yang terdiri dari sungai dan anak sungai alamiah serta sistem saluran drainase dan kanal penampung banjir buatan yang ada tidak mampu menampung akumulasi air hujan sehingga meluap, dan kondisi tersebut berdampak pada timbulnya genangan di wilayah tersebut yang dapat merugikan masyarakat (Rachmat,2014).

Peristiwa banjir setiap tahun berulang, namun permasalahan tersebut sampai saat ini belum terselesaikan. Maka menyebabkan tingginya genangan air sehingga terjadilah banjir yang menyebabkan lumpuhnya ekonomi dan kehidupan sosial pada masyarakat tersebut. Hadirnya bencana banjir dalam kehidupan manusia, menyebabkan adanya kegoncangan psikologis pada diri manusia tersebut. Dimana mereka berusaha menyelamatkan harta benda, kekurangan bahan pangan yang hilang karena banjir. Pekerjaan yang hilang, dan di satu sisi mereka harus berupaya agar kehidupan terus berlanjut sampai ekonomi masyarakat pulih (Rachmat,2014).

Individu yang terkena banjir dapat dipastikan akan mengalami trauma yang dikenal dengan sebutan 
Gangguan Stres Pasca Trauma (PTSD/Post traumatic stresss di sorder) atau Acute Stress Reaction. Oleh karena itu, hadirnya sebuah bencana dalam di kehidupan manusia, menyebabkan adanya kegoncangan psikologis pada diri manusia tersebut. Maka, akibat dari ketidakseimbangan psikologis ini seseorang yang terkena banjir kerap kali memunculkan sikap-sikap yang tidak terduga (National Medical Policy dalam Rahmani 2012).

Gejala kecemasan yang terjadi setelah seseorang telah terkena peristiwa traumatis yang mengakibatkan perasaan ngeri, tidak berdaya atau takut. Gangguan emosional tersebut di alami seseorang setelah mengalami kejadian traumatis. Gangguan tersebut dapat meliputi 3 gejala pokok yakni perasaan mengalami kembali (re-experiencing), keinginan untuk menghindari semua stimulus yang berhubungan dengan peristiwa traumatis (avoidance), dan peningkatan kesadaran yang berlebihan (arousal), yang di alami selama kurun waktu satu bulan atau lebih.

Dari hasil penelitian Muhammad Khoirul Amin (2017) Post Traumatic Stress Pasca Bencana gejala PTSD yang sering muncul yaitu daya ingat yang selalu tertekan dengan peristiwa $(64,5 \%)$,dan mudah terkejut (58,6\%). Intervensi profesional dan efektif diperlukan untuk mereka yang mengalami kehilangan harta benda atau seseorang yang dekat dengannya. Dari survey lapangan di Kelurahan Meranti Pandak dengan mewawancarai 10 orang masyarakat setempat ditemukan data bahwa 7 orang mengatakan merasa cemas, stress terhadap bencana, sulit berkonsentrasi, tidak mampu mengontrol marah, merasa tidak percaya diri dan 3 orang lagi mengatakan tidak merasa cemas dan stress karena masyarakat tersebut tidak terlalu peduli terhadap bencana dan selalu bersikap biasa saja. Namun perlu disadari bahwa kualitas terganggunya aspek kehidupan masyarakat ini tidaklah total, dan hal ini sangatlah tergantung kepada besar kecilnya hazard (ancaman). Bencana tersebut juga dipengaruhi oleh kapasitas masyarakat yang ada serta ketidakmampuan masyarakat (Daryono,2010).

Berdasarkan fenomena diatas bahwa dampak yang ditimbulkan akibat bencana banjir hampir semua aspek kehidupan maka penelitian ini bertujuan untuk mengetahui gambaran tentang gejala PTSD (Post Traumatic Stress Disorder) masyarakat akibat bencana banjir di Kelurahan Meranti Pandak RT 02 RW 012 Kecamatan Rumbai Pesisir Pekanbaru.

\section{BAHAN DAN METODE}

Penelitian ini dilakukan di Wilayah Kelurahan Meranti Pandak RT 02 RW 012 Rumbai Pesisir Pekanbaru. Penelitian ini dilaksanakan pada tanggal 16 Juni- 01 Juli 2019 di RW 012 RT 02 Kelurahan Meranti Pandak Kecamatan Rumbai Pesisir Pekanbaru. Jenis penelitian kuantitatif dan dengan desain deskritif ini jumlah sampelnya adalah 45 kepala keluarga. Instrumen penelitian yang digunakan dalam penelitian ini terdiri dari 2 bagian, yaitu : kuesioner data demografi dan kuesioner tanda dan gejala gangguan strees pascatrauma atau post traumatic stress disorder (PTSD). Kuesioner demografi terdiri dari usia, jenis kelamin, agama, pendidikan, pekerjaan dan suku. Kuesioner yang mengukur tanda dan gejala gangguan stress pascatrauma yang digunakan peneliti dalam penelitian ini merupakan instrument post traumatic stress disorder (PTSD) screening (PCL) yang bersumber dari national center for PTSD (NCPTSD

\section{HASIL}

Berdasarkan hasil dari penelitian didapatkan data dalam bentuk tabel distribusi frekuensi yaitu :

Tabel 1. Distribusi Frekuensi Responden Menurut Usia

\begin{tabular}{llcc}
\hline No & Usia & F & (\%) \\
\hline $\mathbf{1}$ & Masa dewasa awal (26 - 35 Tahun) & 14 & 31,1 \\
$\mathbf{2}$ & Masa dewasa akhir (36 - 45 Tahun) & 17 & 37,8 \\
$\mathbf{3}$ & Masa lansia awal (46 - 55 Tahun) & 9 & 20,0 \\
$\mathbf{4}$ & Masa lansia akhir (56 - 65 Tahun) & 5 & 11,1 \\
& Jumlah & 45 & \\
& & & 100 \\
\hline
\end{tabular}

Berdasarkan tabel 1. Mayoritas usia responden pada masa deswasa akhir berjumlah 17 orang $(37,8 \%)$.

Tabel 2. Distribusi Frekuensi Responden Menurut Jenis Kelamin

\begin{tabular}{llcl}
\hline No & Jenis Kelamin & F & (\%) \\
\hline $\mathbf{1}$ & Laki-laki & 39 & 86,7 \\
$\mathbf{2}$ & Perempuan & 6 & 13,3 \\
& & & 100 \\
\hline
\end{tabular}

Berdasarkan Tabel 2. Mayoritas jenis kelamin responden laki-laki berjumlah 39 orang $(86,7 \%)$

Tabel 3. Distribusi Frekuensi Responden Menurut agama

\begin{tabular}{llcc}
\hline No & Agama & F & (\%) \\
\hline $\mathbf{1}$ & Kristen & 7 & 15,6 \\
$\mathbf{2}$ & Islam & 38 & 84,4 \\
& & & \\
& Jumlah & 45 & 100 \\
\hline
\end{tabular}

Berdasarkan Tabel 3. Mayoritas agama responden islam berjumlah 38 orang $(84,4 \%)$

Tabel 4. Distribusi Frekuensi Responden Menurut Pendidikan

\begin{tabular}{llcc}
\hline No & Pendidikan & F & (\%) \\
\hline $\mathbf{1}$ & Pendidikan Rendah & 21 & 46,7 \\
$\mathbf{2}$ & Pendidikan menengah & 15 & 33,3 \\
$\mathbf{3}$ & Pendidikan Tinggi & 9 & 20,0 \\
& & & \\
& Jumlah & 45 & 100 \\
\hline
\end{tabular}


Berdasarkan Tabel 4. Mayoritas tingkat pendidikan rendah berjumlah 21 orang $(46,7 \%)$.

Tabel 5. Distribusi Frekuensi Responden Menurut Pekerjaan

\begin{tabular}{llcc}
\hline No & Pekerjaan & F & $\mathbf{( \% )}$ \\
\hline $\mathbf{1}$ & Buruh/Petani & 3 & 6,7 \\
$\mathbf{2}$ & PNS & 5 & 11,1 \\
$\mathbf{3}$ & Wiraswasta & 29 & 64,4 \\
$\mathbf{4}$ & Mengurus rumah tangga/tidak & 8 & 17,8 \\
& bekerja & & \\
$\quad$ Jumlah & 45 & 100 \\
\hline
\end{tabular}

Berdasarkan Tabel 5. Mayoritas Pekerjaan wiraswasta/swasta berjumlah 29 orang $(64,4 \%)$.

Tabel 6. Distribusi Frekuensi Responden mengalami gejala PTSD bencana banjir $(\mathrm{f}=45)$

\begin{tabular}{llcc}
\hline No & \multicolumn{1}{c}{ Kategori } & F & (\%) \\
\hline $\mathbf{1}$ & $\begin{array}{l}\text { Pengalaman terulang } \\
\text { a. Mengalami }\end{array}$ & 27 & 60,0 \\
& $\begin{array}{l}\text { b. Tidak mengalami } \\
2\end{array}$ & 18 & 40,0 \\
& $\begin{array}{l}\text { Penghindaran } \\
\text { a. Mengalami }\end{array}$ & 37 & 82.2 \\
& b. Tidak mengalami & 8 & 17.8 \\
$\mathbf{3}$ & $\begin{array}{l}\text { Perubahan Negatif dalam pemikiran } \\
\text { dan susasana hati }\end{array}$ & 10 & 22.2 \\
& $\begin{array}{l}\text { a. Mengalami } \\
\text { b. Tidak mengalami }\end{array}$ & 35 & 77.8 \\
$\mathbf{4}$ & $\begin{array}{l}\text { Perubahan ransangan dan kreatifitas } \\
\text { a. Mengalami }\end{array}$ & 34 & 75.6 \\
& b. Tidak mengalami & 11 & 24.4 \\
& Jumlah & 45 & 100 \\
\hline & & &
\end{tabular}

Berdasarkan Tabel 6 dapat diketahui bahwa gejala PTSD di tinjau dari pengalaman terulang yaitu mayoritas mengalami gejala 27 orang $(60,0 \%)$, Penghindaran mayoritas mengalami gejala 37 orang $(82,2 \%)$, perubahan negatif dalam pemikiran dan suasana hati mayoritas tidak mengalami 35 orang $(77,8$ $\%$ ) dan perubahan ransangan dan kreatifitas mayoritas mengalami 34 orang $(75,6 \%)$.

Tabel 10. Distribusi Frekuensi Responden mengalami gejala PTSD akibat bencana banjir Di Kelurahan Meranti Pandak RT 02 RW 012 Kecamatan Rumbai Pesisir

\begin{tabular}{llll}
\hline No & \multicolumn{1}{c}{ Kategori } & F & (\%) \\
\hline $\mathbf{1}$ & Mengalami semua gejala PTSD & 3 & 6,7 \\
$\mathbf{2}$ & Tidak Mengalami semua gejala & 42 & 93, \\
& PTSD & & 3 \\
& Jumlah & 45 & 100 \\
\hline
\end{tabular}

Berdasarkan Tabel 10 dapat diketahui bahwa mayoritas responden yang tidak mengalami keempat gejala PTSD berjumlah 42 orang $(93,3 \%)$, sedangkan yang mengalami keempat gejala PTSD berjumlah 3 orang $(6,7 \%)$.

\section{PEMBAHASAN}

Individu yang mengalami gejala PTSD dipengaruhi oleh beberapa faktor yaitu usia, jenis kelamin, pendidikan, agama pekerjaan. Berdasarkan faktor tersebut induvidu juga memiliki kemampuan memulihkan dan mempertahankan tingkat kesehatan fisik dan emosional setelah mengalami suatu trauma. Sesuai dengan pendapat Weems (2010) yang menjelaskan bahwa faktor resiko yang menyebabkan seseorang mengalami PTSD diantaranya ialah usia, jenis kelamin, agama dan pendidikan. PTSD dapat terjadi pada semua golongan usia tetapi anak-anak, usia dewasa dan lansia merupakan usia yang lebih rentan mengalami PTSD. Anak-anak memiliki kebutuhan dan kerentanan khusus jika dibandingkan dengan orang dewasa, karena masih adanya rasa ketergantungan dengan orang lain, kemampuan fisik dan intelektual yang sedang berkembang, serta kurangnya pengalaman hidup dalam memecahkan berbagai persoalan sehingga dapat mempengaruhi perkembangan kepribadian seseorang.

Hasil penelitian ini mayoritas berada pada usia dewasa akhir antara 36 - 45 tahun, pada umumnya responden merupakan kepala keluarga. Sesuai dengan hasil penelitian Suwarningsih (2018), pada korban pasca banjir bandang di Kota Garut Jawa Barat $95 \%$ usia responden pada rentang 36 sampai 39 tahun dari 150 responden. Bahwa semakin tua usia korban, maka korban tersebut akan semakin rentan dengan kemungkinan terjadinya gangguan psikososial. Hasil penelitian juga diperkuat dengan penelitian Oyama (2012) pasca 3 tahun gempa di Jepang. Penelitian ini menemukan bahwa $24 \%$ mengalami stress psikologis.

Berdasarkan jenis kelamin perempuan akan memiliki resiko lebih besar mengalami PTSD dari pada laki-laki. Hal ini dikarenakan, rendahnya sintesa serotonin yang ada pada perempuan. Sintesa serotonin akan membawa pesan kimia pada neurotransmitter pada otak yang akan memberikan komunikasi antara sel-sel saraf otak. Menurut Suwarningsih (2018) pria lebih tanggung dalam menghadapi krisis

Berdasarkan nilai keimanan dengan mayoritas islam individu membantu mempertahankan kesehatan mental individu pada saat-saat sulit. Dapat menerima kenyataan dengan selalu ridha dan tawakal mempercepat proses pemulihan terhadap trauma. Hasil penelitian Ellison menunjukan bahwa individu yang memiliki kepercayaan terhadap agama yang kuat, dilaporkan memiliki kepuasan hidup yang lebih tinggi, kebahagiaan personal yang lebih tinggi, serta mengalami dampak negatif peristiwa traumatis yang lebih rendah jika dibandingkan individu yang tidak memiliki kepercayaan terhadap agama yang kuat. Kehidupan religius atau keagamaan dapat membantu manusia dalam menurunkan kecemasan, kegelisahan, dan ketegangan.

Pendidikan yang dibawah rata-rata, perilaku orang tua yang negatif, kemiskinan orang tua merupakan prediktor perkembangan PTSD.Tingkat 
pendidikan juga dapat mempengaruhi strategi koping individu. Menurut peneliti seseorang yang memiliki pendidikan rendah sedikit mendapatkan informasi tentang strategi koping/ketahanan jika terdapat bencana. Dari data di atas banyak masyarakat dengan pendidikan terakhir sekolah dasar. Hal ini disebabkan kurang terampilnya menggunakan mekanisme koping, saat terjadi kehilangan dan berduka akibat bencana. Kebanyakan saat bencana panik dan khawatir terhadap berbagai hal, hal ini dapat mengarahkan kepada koping yang destruktif. Sehingga rentan mengalami PTSD.

Faktor etnik dan sosio ekonomi merupakan faktor resiko yang penting. Faktor sosio ekonomi sulit untuk dikaji pada beberapa penelitian, karena dampak komunitas yang relatif homogen. Walaupun demikian, sebagian besar penelitian menyatakan bahwa pendidikan yang rendah dan penghasilan yang rendah merupakan faktor resiko terdampak morbiditas psikososial. Individu dapat menanggulangi stress dan kecemasan dengan menggunakan atau mengambil sumber koping dari lingkungan baik dari sosial, intrapersonal dan interpersonal. Sumber koping diantaranya adalah aset ekonomi, kemampuan memecahkan masalah, dukungan sosial budaya yang diyakini (Suliswati,2010).

Berdasarkan hasil penelitian yang dilakukan di RW 012 RT 02 Kelurahan Meranti Pandak Kecamatan Rumbai Pesisir, didapatkan bahwa mayoritas gejala PTSD di tinjau dari pengalaman terulang yaitu sebanyak 27 orang $(60,0 \%)$ yang mengalami. Merasakan kembali kejadian traumatis dalam berbagai cara dan hal ini terjadi terus menerus dan menetap. Dengan munculnya tanda dan gejala tersebut, trauma akan dirasakan kembali oleh individu yang menderita PTSD melalui mimpi, memori atau masalah yang merupakan respon karena teringat tentang trauma yang di alami. (National Center of PTSD,2009).

Individu kerap teringat pada kejadian tersebut dan mengalami mimpi buruk tentang hal itu. Penderitaan emosional yang mendalam ditimbulkan oleh stimuli yang menyimbolkan kejadian tersebut, atau tanggal terjadinya pengalaman tertentu. Pentingnya "mengalami kembali kejadian" tidak dapat diremehkan karena kemungkinan merupakan penyebab simptom-simptom kategori lain. Beberapa teori PTSD membuat "mengalami kembali" sebagai ciri utama dengan mengontribusikan gangguan tersebut pada ketidakmampuan untuk berhasil mengintegrasikan kejadian traumatic ke dalam skema yang ada saat ini.

Menurut penelitian Elita (2017) bisa berlangsung berbulan-bulan bahkan bertahun-tahun atau mungkin baru muncul setelah beberapa bulan maupun tahun. Foa (2010) tetang pengolahan trauma kognitif sangat sulit dilakukan oleh orang yang mengalami PTSD, hal ini dikarenakan dalam mengaktifkan struktur ketakutan berarti mengaktifkan unsur respon, sehingga ketika individu merasakan emosi yang luar biasa seseorang kemudian mencoba untuk berhenti berfikir tentang kejadian masa lalu.
Kemudian berkembang antara upaya untuk mengasimilasi (yang mengarah ke pengalaman yang terulang), dan upaya untuk menghindari ingatan dan emosi negatif. Oleh karena itu seseorang yang mengalami PTSD akan menghindari stimuli yang mengingatkan tentang pengalaman trauma yang pernah dialami.

Berdasarkan hasil penelitian yang dilakukan di RW 012 RT 02 Kelurahan Meranti Pandak Kecamatan Rumbai Pesisir, didapatkan bahwa mayoritas gejala PTSD di tinjau dari penghindaran yaitu sebanyak 37 orang $(82,2 \%)$ yang mengalami. Orang yang bersangkutan berusaha menghindari untuk berfikir tentang trauma atau menghadapi stimuli yang akan mengingatkan pada kejadian tersebut. Mati rasa adalah menurunnya ketertarikan pada orang lain, suatu rasa keterpisahan, dan ketidakmampuan untuk merasakan sebagai emosi positif. Pada PTSD kenyataannya terdapat suatu fluktuasi: penderita bergantian mengalami kembali dan mati rasa.

Hal-hal yang bisa mengingatkan klien terhadap trauma bisa bersumber dari diri klien sendiri, seperti pikiran atau perasaan tentang trauma yang di alami, atau bisa juga karena adanya stimulus dari luar atau lingkungan yang mampu membangkitkan memori atau perasaan yang tidak menyenangkan. Selain itu, tanda dan gejala PTSD pada kelompok ini meliputi penurunan kemampuan emosional, merasa jauh dari orang lain dan tidak memiliki cita-cita atau harapan yang akan dipenuhi untuk masa depannya (National Center Of PTSD,2009).

Berbeda dengan hasil penelitian Endiyono (2018) ditemukan sebanyak 78,9 \% yang memenuhi kriteria diagnostic PTSD. Hasil penelitian yang dilakukan oleh Giacco, dkk (2013) menyatakan bahwa hasil penelitian terhadap responden yang terdiagnosis PTSD di dusun Jemblung Kabupaten Banjarnegara mengalami gejala terbanyak berupa negatif alteration in mood and cognition, re-experiencing dan avoidance (menghindar), faktor penyebab mengapa gejala ini masi saja dialami seperti lingkungan yang baru, harus memulai kehidupan baru, harus memulai kehidupan dari nol karena harta benda yang hilang.

Berdasarkan hasil penelitian yang dilakukan di RW 012 RT 02 Kelurahan Meranti Pandak Kecamatan Rumbai Pesisir, didapatkan bahwa mayoritas gejala PTSD di tinjau dari Perubahan negatif dalam pemikiran dan suasana hati (mood) yaitu sebanyak 35 orang $(77,8 \%)$ yang tidak mengalami.. Ketidakmampuan mengingat bagian dari peristiwa traumatis, kepercayaan dan perasaan negatif tentang diri sendiri, ketidakmampuan untuk menikmati aktifitas yang menyenangkan, atau menyalahkan diri sendiri atas trauma atau konsekuensinya. Mereka yang mengalami PTSD dapat menunjukkan keterpisahan emosional, isolasi sosial, dan kesepian. Keadaan dimana seseorang memiliki perasaan dan fikiran yang semakin jelek setelah trauma. Gejala ini ditandai dengan ketidakmampuan untuk mengingat kembali poin-poin penting dari kejadian traumatis yang dialami, memiliki fikiran tentang diri sendiri atau lingkungan sekitar, 
menyalahkan diri sendiri atau lingkungan sekitar, menyalahkan diri sendiri atau orang lain sebagai penyebab terjadinya kejadian traumatis, merasa terisolasi, adanya penurunan minat terhadap aktifitas, adanya perasaan emosional yang negatif (seperti rasa takut, horror, dan malu), dan kesulitan untuk mengekspresikan perasaan emosional yang positif.

Berdasarkan hasil penelitian yang dilakukan di RW 012 RT 02 Kelurahan Meranti Pandak Kecamatan Rumbai Pesisir, didapatkan bahwa mayoritas gejala PTSD di tinjau dari Perubahan rangsangan atau kreatifitas yaitu sebanyak 34 orang $(75,6 \%)$ yang mengalami. Simptom-simptom ini mencangkup sulit tidur atau mempertahankannya, sulit berkonsentrasi, waspada berlebihan, dan respon terkejut yang berlebihan. Berbagai studi laboratorium menegaskan simton-simton klinis ini dengan mendokumentasikan meningkatnya reaktifitas fisiologis pada pasien penderita PTSD terhadap pencitraan pertempuran dan respon-respon terkejut yang sangat tinggi. Masalah lain yang sering dihubungkan dengan PTSD adalah gangguan anxiety lain, depresi, kemarahan, rasa bersalah, penyalahgunaan zat, masalah perkawinan, kesehatan fisik yang rendah dan disfungsi seksual.

Individu yang menderita PTSD akan mengalami peningkatan pada mekanisme fisiologis tubuh, yang akan timbul pada saat tubuh sedang istirahat. Hal ini terjadi sebagai akibat dari reaksi yang berlebihan terhadap stressor baik secara langsung atau tidak yang merupakan lanjutan atau sisa-sisa dari trauma yang dirasakan. Tanda dan gejala pada kelompok ini biasanya merupakan salah satu cara untuk mengatasi trauma yang dirasakan, contohnya adalah gangguan tidur merupakan akibat dari mimpi buruk yang dialami klien. (National Center of PTSD).

Berdasarkan hasil penelitian yang dilakukan di RW 012 RT 02 Kelurahan Meranti Pandak Kecamatan Rumbai Pesisir, didapatkan bahwa mayoritas yang tidak mengalami keempat gejala PTSD sebanyak 42 orang $(93,3 \%)$ sedangkan yang mengalami keempat gejala PTSD sebanyak 3 orang (6,7\%). Gangguan PTSD berkaitan erat dengan penurunan kualitas hidup seseorang. Analisis hasil penelitian terhadap gambaran keempat gejala PTSD terhadap perubahan kualitas hidup menunjukan adanya gejala yang signifikan. Ada beberapa factor yang menjadi penyebab mengapa gejala ini masih saja dialami seperti lingkungan yang baru, harus memulai kehidupan dari nol karena harta benda yang hilang.

\section{SIMPULAN}

Mayoritas usia responden masa dewasa akhir yaitu $(37.8 \%)$, mayoritas jenis kelamin laki-laki yaitu (86,7\%), mayoritas agama yaitu islam (84,4\%), pendidikan rendah (SD/SMP/MTS) yaitu (46,7\%), dan mayoritas pekerjaan wiraswasta/swasta yaitu $(64,4 \%)$.Mayoritas responden yang mengalami gejala PTSD di tinjau dari pengalaman terulang $(60,0 \%)$, di tinjau dari penghindaran $(62,2 \%)$, di tinjau dari perubahan negatif dalam pemikiran dan suasana hati (mood) tidak mengalami (77,8\%), di tinjau dari perubahan rangsangan atau kreatifitas sebanyak (75,6\%). Responden yang tidak mengalami keempat gejala PTSD yaitu (93,3\%).

Bagi kelurahan Meranti Pandak kecamatan Rumbai Pesisir melalui petugas kesehatan lebih aktif lagi dalam rangka mengadakan dan mengikuti kegiatan penyuluhan dan penelitian ini diharapkan dapat bermanfaat bagi yang akan melakukan penelitian dengan materi yang sama dimasa yang akan datang sebagai bahan tambahan literatur bacaan.

\section{DAFTAR PUSTAKA}

Depsos. 2012. Perempuan dan bencana. Retrieved from www.depsos.go.id website:

Elita dkk, 2017, Acceptance and Commitment Therapy (ACT) Bagi Penderita Gangguan Stress Pasca Bencana, Jurnal Konseling dan Pendidikan Vol. 5 No.2 Tahun 2017: 1-5.

Endiyono, Hidayah Novi Isnaini, 2018, Gambaran Post Traumatic Stress Disorder Korban Bencana Tanah Longsor Di Dusun Jemblung Kabupaten Banjarnegara, Jurnal Ilmiah ilmuilmu Kesehatan Vol.16 No.3 Tahun 2018: 1-5.

National Institute of mental health. 2008. Post Traumatic Stress Disorder. National institute of mental health. Available from:http://www.nimh.nih.gov/health/publi cations/post-traumatic-stress-disorderptsd/what-is-post-traumatic-stress-diosorderor-ptsd.shtml.

Perka BNPB No. 10 Tahun 2008 tentang pedoman komando tanggap darurat.

PP Nomor 21 Tahun 2008 Tentang penyelenggaraan Penanggualangan bencana.

Perka BNPB Nomor 4 Tahun 2008 tentang pedoman penyusunan rencana penanggualangan bencana.

Rachmat, A. R., \& Pamungkas, A. 2014. Faktor-faktor Kerentanan yang Berpengaruh Terhadap Bencana Banjir di Kecamatan Manggala Kota Makassar. Jurnal Teknik Pomits, Vol. 3 No. 2 Tahun 2014 C-178.

Rahmania, A. R. 2012. Perbedaan Pengaruh Eye Movement Desensitization And Reprocessing (Emdr) Dengan Teknik Stabilisasi Untuk Menurunkan Posttraumatic Stress Disorder (Ptsd) Pada Penyandang Tuna Daksa Pasca Mengalami Kecelakaan Lalu Lintas. Jurnal Intervensi Psikologi, Vol. 4 No. 2 Tahun 2012

Suwarningsih, dkk, 2018, Perubahan Kondisi Psikososial Dan Spiritual Pada Korban PTSD (Post Traumatic Stress Disorder) Pasca Banjir Bandang Di Kota Garut Jawa Barat, Jurnal Ilmiah Kesehatan, Vol. 11 No.1 Tahun 2019:1-11.

Undang-Undang No. 24 Tahun 2007 tentang Penanggulangan Bencana. Jakarta. 